\title{
4Kekuatan Tarik Dan Lentur Komposit Poliester Berpenguat Serat Cordyline Australis (Daun Praksok) Dengan Perlakuan Air Laut
}

\author{
Ida Bagus Putu Purwadnyana ${ }^{1)}$, Tjokorda Gde Tirta Nindhia' ${ }^{2)}$, I Wayan Surata ${ }^{3)}$ \\ Program Studi Teknik Mesin Universitas Udayana, Kampus Bukit Jimbaran Bali \\ Jl. Raya Kampus Unud, Jimbaran, Kec. Kuta Selatan, Kabupaten Badung, Bali Telp: 0361-703321 \\ Website: https://mesin.unud.ac.id, E-mail: goestwopurwa@gmail.com
}

\begin{abstract}
Abstrak - Komposit didesain untuk menjadi material alternatif pengganti logam. Unsur utama dari komposit adalah serat dan matriks, serat adalah sumber dari kekuatan dan kekakuan pada komposit. Tujuan dilakukannya penelitian ini untuk mengetahui pengaruh fraksi berat dan waktu perendaman serat pada air laut terhadap kekuatan tarik dan kekuatan lentur dari komposit serat praksok. Pada penelitian ini digunakan serat alam yaitu serat praksok. Serat direndam pada air laut selama 0, 2, dan 4 jam. Resin yang digunakan merupakan resin epoxy dengan merek sikadur 52-id. Komposit menggunakan serat daun praksok dengan pajang $3 \mathrm{~cm}$ dan disusun secara acak menggunakan metode hand lay-up dengan fraksi berat serat 0\%, 5\%, dan 7,5\%. Spesimen pengujian tarik komposit menggunakan standar ASTM D3039 dan uji lentur menggunakan ASTM D790. Hasil penelitian menunjukan kekuatan tarik dan kekuatan lentur tertinggi terjadi pada fraksi berat serat 7,5\% perendaman serat 2 jam dengan nilai rata-rata kekuatan tarik sebesar 31,316 MPa dan kekuatan lentur sebesar 74,552 MPa. Pada pengamatan foto makro patahan, ikatan serat dan matriks terbaik terdapat pada variasi perendaman serat 2 jam sehingga kekuatan tarik dan lentur dapat dihasilkan secara optimum. Ikatan serat dan matriks yang baik ditandai dengan terdapatnya overload pada patahan.
\end{abstract}

Kata Kunci: Serat daun praksok, fraksi berat serat, waktu perendaman serat, kekuatan tarik, kekuatan lentur.

\begin{abstract}
Composites are designed to be an alternative material made of metal; the material is lightweight, corrosion resistant and inexpensive. The main element of a composite is a fiber and matrix, fiber is a material that provides strength and stiffness in a composite. The purpose of this study are to identify the effect of weight fraction and fiber immersion time in sea water against tensile and flexural strength of praksok leaf fiber composites. In this study natural fibers such as prasok (cordyline australis) fiber are used. The fiber is submerged in sea water for 0, 2, and 4 hours with $3 \mathrm{~cm}$ fiber length. The resin used is epoxy resin with the brand sikadur 52-id. Composite was made with random fiber orientation by hand lay-up method with weight fraction of 0\%, 5\%, and 7.5\%. Composite tensile testing using ASTM D3039 standard and flexural testing using ASTM D790. The results of the study of the prasok leaf fiber reinforced composites with fiber weight fraction of $0 \%, 5 \%$, and 7,5\%, therefore highest tensile and flexural strength were occurred at $7.5 \%$ fiber weight fraction of 2 hour fiber immersion with an average tensile strength value of $31.316 \mathrm{MPa}$ and flexural strength value of $74.552 \mathrm{MPa}$. In the observation of fracture macro photos, the best cross-linking bond is found in the variation of fiber immersion for 2 hours so that tensile and flexural strength occur optimally.
\end{abstract}

Keywords: Prasok leaf fiber, fiber weight fraction, fiber immersion time, tensile strength, flexural strength.

\section{PENDAHULUAN}

Perkembangan teknologi komposit sangat berpengaruh pada industri manufaktur. Komposit didesain untuk menjadi material alternatif pengganti logam, komposit memiliki beberapa keunggulan dari logam seperti; materialnya ringan, tahan korosi dan murah. Komposit memiliki strength to weight ratio yang lebih baik dari logam, sehingga komposit cocok untuk menjadi material alternatif pengganti logam [1]. Komposit adalah material yang terdiri dari campuran dua atau lebih material yang memiliki sifat fisik dan kimia yang berbeda antar material penyusunnya. Komposit tersusun dari matriks dan serat atau fiber (reinforcement). Diperlukan teknologi komposit baru dimana material dari komposit itu dibuat agar ramah lingkungan seperti memanfaatkan serat alam dibandingkan dengan serat sintetis. Dimana dengan menggunakan serat alam ditujukan untuk meminimalisir kontaminasi lingkungan, emisi gas efek rumah kaca, dan memaksimalkan penggunaan sumber daya alam. Serat alam yang digunakan untuk reinforcement dari komposit merupakan serat yang didapat melalui proses ekstraksi dari tumbuhan, salah satau proses ekstraksi yang umum digunakan adalah waterretting. Sifat suatu material komposit dapat ditentukan oleh komposisi serat yang terkandung didalamnya, bahwa semakin banyak serat yang terdapat didalamnya maka kekuatan mekaniknya semakin besar. Peningkatan kekuatan dan kekakuan dapat dicapai dengan memvariasikan fraksi berat serat dan mengontrol ikatan antara lapisan komposit [2]. Perlakuan kimia seperti perendaman serat pada larutan alkali sering kali digunakan pada penelitian komposit berserat alam. Penggunaan larutan alkali pada 
perendaman serat alam berfungsi untuk melepaskan/membersihkan lapisan lilin (lignin) pada permukaan serat alam. Lapisan lilin dihilangkan untuk meningkatkan ikatan serat dengan matriks sehingga menghasilkan sifat mekanis komposit yang lebih baik [3]. Penggunaan air laut sebagai perlakuan larutan alkali bertujuan untuk mencari alternatif larutan alkali alami pengganti $\mathrm{NaOH}$, dimana air laut mengandung $3,5 \% \mathrm{NaCl}$ dengan variasi durasi waktu perendaman untuk dapat mengetahui durasi waktu perlakuan air laut yang paling optimum terhadap ikatan serat dan matriks. Penelitian ini mengacu pada pembuatan komposit berpenguat serat cordyline australis dengan matriks epoxy sebagai pengikat. Penelitian ini bertujuan untuk mendapatkan data ilmiah mengenai pengaruh waktu perendaman air laut terhadap perubahan sifat-sifat mekanis serat pembentuk material komposit, serta pengaruh fraksi berat terhadap peningkatan nilai kekuatan tarik dan kekuatan lentur komposit. Metode penelitian ini dimulai dengan pemisahan (ekstraksi) daun menjadi serat, pembuatan spesimen dengan metode pencetakan dengan teknik hand lay-up, dilanjutkan dengan pengujian uji tarik ASTM D3039 dan uji lentur ASTM D790-03.

Dalam penelitian ini ada beberapa masalah yang akan dikaji, yaitu:

1. Bagaimana pengaruh perlakuan perendaman serat pada air laut dan fraksi berat serat terhadap kekuatan tarik komposit epoxy serat cordyline australis yang dicetak dengan teknik hand lay-up?

2. Bagaimana pengaruh perlakuan perendaman serat pada air laut dan fraksi berat serat terhadap kekuatan lentur komposit epoxy serat cordyline australis yang dicetak dengan teknik hand lay-up?

\section{LANDASAN TEORI}

\subsection{Komposit}

Komposit merupakan sistem material yang tersusun dari dua atau lebih kombinasi unsur pokok yang memiliki komposisi kimia yang berbeda dan pada dasarnya tidak larut satu sama lain [4]. Komposit memiliki kekuatan jenis (modulus elastisitas /densitas) dan kekuatan jenis lebih tinggi dibandingkan logam. Serat berfungsi sebagai rangka dan matriks sebagai pengisi dari rangka dan pengikat serat. Matriks juga berfungsi sebagai komponen pada komposit yang meneruskan beban eksternal ke serat secara merata. Penggabungan matriks dengan serat alam membutuhkan ikatan permukaan yang kuat agar reaksi yang terjadi dapat serasi dan saling berhubungan antara satu dengan yang lainnya. Sifat pengikatan ini dapat ditingkatkan dengan perlakuan kimia pada serat alam [5].

\subsection{Serat (Penguat)}

Serat merupakan bahan utama dari komposit, fungsi serat umumnya adalah sebagai rangka material untuk memperkuat komposit sehingga sifat-sifat mekaniknya lebih kuat, kaku, tangguh, dan lebih kokoh bila dibandingkan dengan tanpa serat penguat [6]. Serat diklasifikasikan menjadi dua jenis yaitu: serat sintetis dan serat alami.

1) Serat Alam

Serat alam merupakan serat yang diperoleh dari tumbuhan, hewan, dan mineral melalui sebuah proses maupun secara langsung. Serat alam dapat digunakan sebagai komponen dari komposit, dan orientasi serat tersebut akan berdampak pada sifat fisik dari komposit tersebut.

2) Serat Sintetis

Serat sintetis (buatan) merupakan serat yang memiliki susunan molekul yang tersusun secara disengaja yang dibuat oleh manusia melalui suatu proses kimia. Komposit serat sintetis memberikan kekuatan dan keuletan yang lebih dibandingkan komposit serat alam.komposit serat alam memiliki keterbatasan pada aplikasi tertentu dikarenakan kemampuan serat alamnya yang dapat menyerap kelembaban dan stabilitas termal yang lebih rendah dari serat sintetis [7].

\subsection{Matriks (Resin)}

Matriks (resin) adalah material penyusun komposit dimana matriks ini berfungsi sebagai perekat serat, pelindung serat, dan mentransfer beban dari serat ke serat lainnya. Resin akan saling mengikat dengan material serat sehingga beban yang dikenakan pada komposit menyebar secara merata. Matriks memiliki kekerasan, kekakuan, keuletan yang lebih rendah dibandingkan serat. Resin dibagi menjadi dua jenis berdasarkan bahan pembuatnya, yaitu: resin sintetis dan resin alami (bioresin).

\subsection{Serat Cordyline Australis}

Serat Cordyline Australis merupakan serat yang bisa didapatkan dari tumbuhan Cordyline Australis dimana tanaman ini dikenal dengan tanaman Praksok. Tanaman yang berasal dari New Zealand, Australia ini merupakan tanaman hias yang sering digunakan untuk mempercantik rumah dan di Bali biasanya tanaman praksok dimanfaatkan seratnya untuk dijadikan kerajinan seperti rambut pada barong atau rangda. Tinggi pohon praksok bisa mencapai 12 meter dengan panjang daun yang mampu mencapai 1 meter. Serat diperoleh dengan menggunakan metode ekstraksi serat yang disebut water retting dimana metode jenis ini menggunakan media air sebagai pemisah serat dengan unsur lainnya seperti ditunjukan pada gambar 1 . Untuk daun yang baik dimanfaatkan pada pembuatan serat adalah daun ke 3 sampai ke 5 pada pohon praksok yang diukur dari daun paling bawah, dikarenakan daun pada urutan tersebut akan lebih 
mudah di proses menjadi serat dikarenakan umur daun yang lebih muda. Masing-masing serat praksok akan dipotong menjadi $3 \mathrm{~cm}$ untuk dicetak pada komposit sesuai dengan fraksi berat serat yang telah ditentukan.

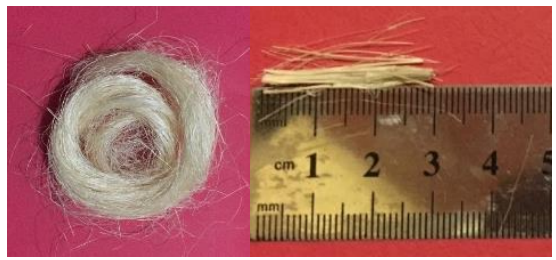

Gambar 1 Serat Praksok (Cordyline Australis)

\subsection{Resin Epoxy}

Resin epoksi (epoxy resin) atau secara umum dipasaran dikenal dengan bahan epoksi adalah salah satu dari jenis polimer yang berasal dari kelompok termoset. Resin termoset adalah polimer cair yang jaringan silang dan juga secara kimia, membentuk tergantung pada unit molekuler yang membentuk jaringan rapat dan panjang jaringan silang. Proses pembuatannya dapat dilakukan pada suhu kamar dengan memperhatikan zat-zat kimia yang digunakan sebagai pengontrol polimerisasi jaringan silang agar didapatkan sifat optium bahan.

Termoset memiliki sifat isotropis dan peka terhadap suhu, mempunyai sifat tidak bisa meleleh, tidak bisa diolah kembali, atomnya berikatan dengan kuat, tidak bisa mengalami pergeseran rantai. Bentuk resin epoksi sebelum pengerasan berupa cairan seperti madu dan setelah pengerasan akan berbentuk padatan yang sangat getas [8].

\subsection{Metode Pencetakan Komposit}

Terdapat dua jenis cara pembuatan komposit, proses cetakan terbuka (open-mold process) dan cetakan tertutup (closed-mold process). Dalam penelitian ini digunakan proses cetakan terbuka yaitu dengan metode hand lay-up. Metode pencetakan hand lay-up diawali dengan pemerataan serat pada cetakan, lalu penuangan resin pada cetakan dan didiamkan selama 24 jam dengan diberikan beban seberat $5 \mathrm{~kg}$ pada tutupnya.

\subsection{Air Laut}

Air adalah substansi yang paling banyak terdapat di bumi. Laut di Bumi memiliki volume sebesar 1.335.000.000 kilometer kubik yang mencakup sekitar 96,5\% dari seluruh air di Bumi yang diketahui dan meliputi lebih dari 70\% permukaan Bumi [9]. Air laut memiliki enam komposisi terbesar yaitu adalah chloride $\left(\mathrm{Cl}^{-}\right)$, sodium $\left(\mathrm{Na}^{+}\right)$, sulfate $\left(\mathrm{SO}_{4}{ }^{2-}\right)$, magnesium $\left(\mathrm{Mg}^{2+}\right)$, calcium $\left(\mathrm{Ca}^{2+}\right)$, and potassium $\left(\mathrm{K}^{+}\right)$(Duxbury \& History, 2018). Akan tetapi komposisi ini sangat bervariasi sebab adanya penambahan unsur lain dari sungai, penguapan, hujan, dan lain-lain. diubah menjadi bahan padat secara polimerisasi formasi rantai polimer tiga dimensi. Sifat mekanisnya

\subsection{Fraksi Berat}

Untuk menentukan jumlah serat daun praksok yang digunakan dapat menggunakan fraksi volume (Fv) dan fraksi berat (Fb). Pada penelitian ini digunakan fraksi berat kering dengan persamaan sebagai berikut:

$\mathrm{w}_{\mathrm{c}}=\mathrm{w}_{\mathrm{f}}+\mathrm{w}_{\mathrm{m}}, \mathrm{F}_{\mathrm{b}}=\frac{\mathrm{w}_{\mathrm{f}}}{\mathrm{w}_{\mathrm{c}}} \times 100 \%$

\subsection{Uji Tarik}

Uji tarik merupakan pengujian material yang bertujuan untuk mengetahui kekuatan tarik, tegangan dan regangan. Pada pengujian ini dilakukan pengamatan terhadap pertambahan beban dan pertambahan panjang selama pengujian. Spesimen pengujian tarik didesain berdasarkan ASTM D3039 yang ditunjukan pada gambar 2 .

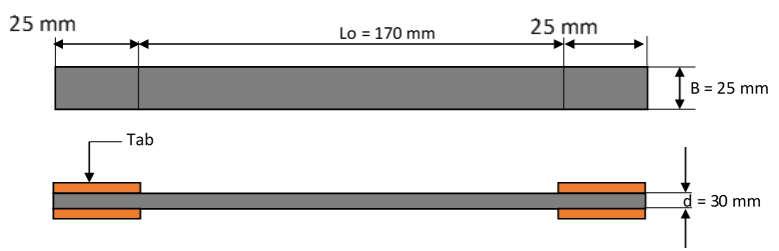

Gambar 2 Spesimen Uji Tarik

Perhitungan tegangan tarik, regangan tarik, dan modulus elastisitas menggunakan persamaan:

$\sigma=\frac{r}{v}, \varepsilon=\frac{\nu-L_{0}}{v}=\frac{\Delta L}{v}, \mathrm{E}=\underline{u y}$

\subsection{Uji Lentur}

Uji lentur merupakan pengujian yang bertujuan untuk mengetahui kekuatan terhadap bending atau pembengkokan. Pada pengujian ini menggunakan metode threepoint bending menggunakan jenis tumpuan jepit - jepit. Spesimen yang akan diuji akan mengalami tegangan tekan pada bagian atas dan tegangan tarik pada bagian bawahnya yang akan didapat beban oleh benda uji sebelum terjadi patahan. Spesimen uji lentur dibuat sesuai standar ASTM D790-03 yang ditunjukkan pada gambar 3.

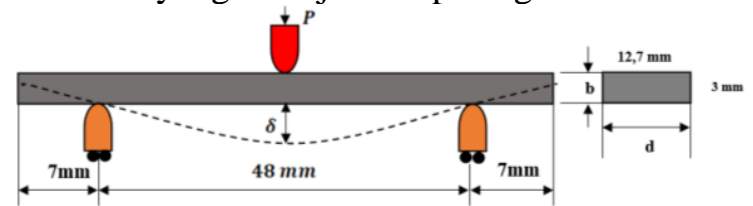

Gambar 3 Spesimen Uji Lentur

Tegangan lentur, regangan lentur, dan modulus elastisitas lentur dapat dihitung dengan persamaan:

$\sigma_{b}=\frac{3 P \ell}{2 b d^{2}}, \varepsilon_{l}=\frac{6 \delta \cdot d}{L^{2}}, \mathrm{E}=\frac{1^{3} \mathrm{~m}}{4 \mathrm{bd}^{3}}$

\subsection{Pengamatan Permukaan Patah}

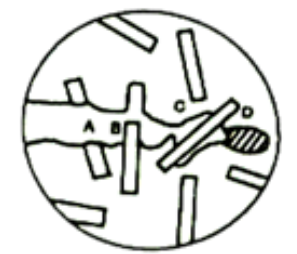


Gambar 4 Pengamatan Permukaan Patah (Sumber: Kresnasandi et al., 2020)

Pada gambar 4 (A) overload, merupakan patahan dari serat yang berhasil terikat dengan matriks dan letaknya sejajar dengan arah dari gaya tarik. (B) Fiber pull-out, merupakan serat yang tidak terikat atau memiliki ikatan yang kurang baik dengan matriks. (C) delamination disebabkan karena tingginya tegangan interlaminar. (D) matriks flow, merupakan patahan matriks yang menyebabkan terjadinya pergeseran alur pada matriks.

\section{METOdOLOGI PENELITIAN \\ 3.1 Alat-alat Penelitian}

Penggunaan alat-alat dalam penelitian ini sebagai berikut :

1. Spesimen uji tarik ASTM D3039

2. Spesimen uji lentur ASTM D790

3. Mikroskop optik

4. Cetakan akrilik

5. Timbangan digital

\subsection{Bahan-bahan Penelitian}

1. Serat daun praksok (cordyline australis)

2. Epoxy sikadur 52-id

3. Air laut

\subsection{Prosedur Penelitian}

1. Menyiapkan daun prasok, diambil dari daun dengan urutan 3-5 dari yang paling bawah untuk memudahkan proses ekstraksi.

2. Proses ekstraksi daun praksok menjadi serat menggunakan teknik waterretting. Serat dipotong menjadi $3 \mathrm{~cm}$.

3. Siapkan cetakan akrilik dengan ukuran cetakan 25 $\mathrm{cm}$ x $25 \mathrm{~cm}$ dan tebal $3 \mathrm{~mm}$. Skema pencetakan komposit ditunjukan pada gambar 4

4. Tata serat pada cetakan secara acak dan merata pada cetakan sesuai dengan jumlah serat dengan perhitungan fraksi berat.

5. Tuangkan matriks epoxy sikadur 52-id pada cetakan sesuai dengan perhitungan fraksi berat.

6. Cetakan ditutup dan diberi beban pemberat $5 \mathrm{~kg}$ selama 24 jam.

7. Lepaskan komposit yang telah dicetak dengan hati-hati.

8. Potong komposit sesuai dengan ukuran spesimen untuk uji tarik dan uji lentur.

9. Spesimen pengujian tarik dengan standar astm d 3039. Data beban diambil setiap $0,1 \mathrm{~mm}$ pertambahan panjang.

10. Spesimen pengujian lentur dengan standar Astm d790-03. Data beban diambil setiap 0,1 mm pertambahan panjang.

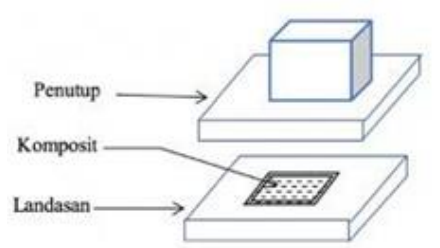

Gambar 5 Skema Pencetakan Komposit

\section{HASIL DAN PEMBAHASAN}

\subsection{Uji Tarik}

Data hasil uji tarik untuk semua perlakuan dan fraksi berat serat disajikan pada tabel 1 .

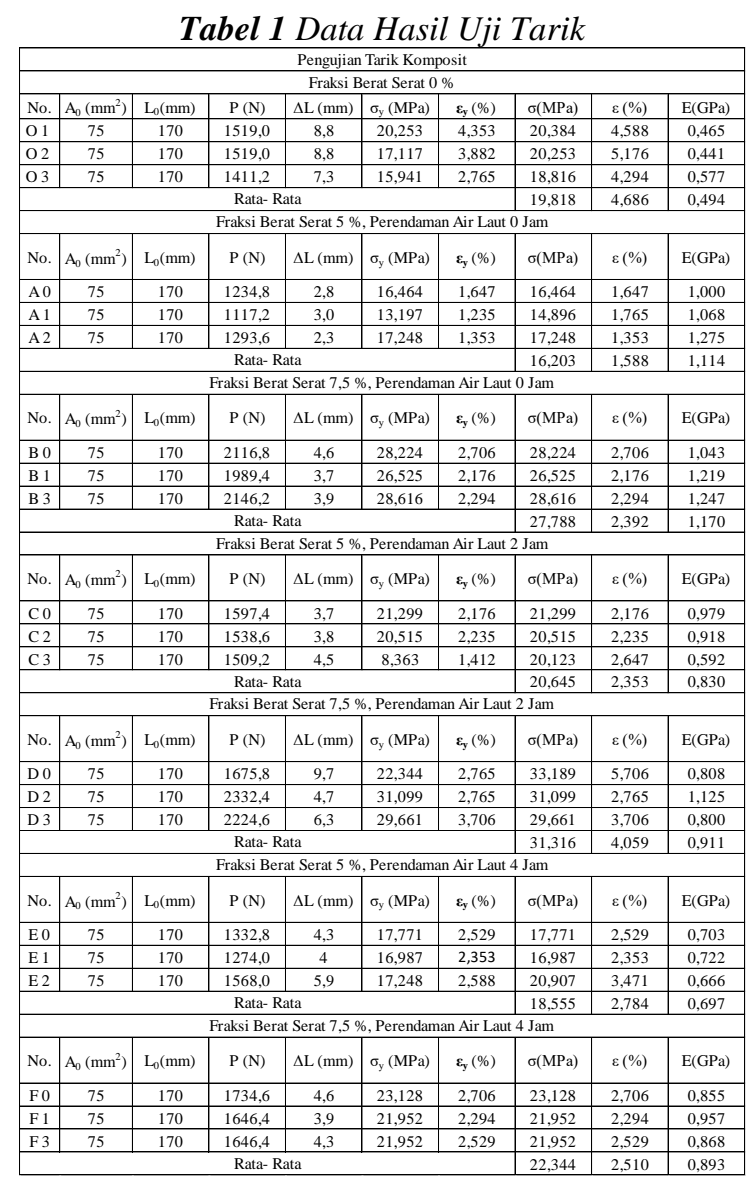

Berdasarkan data yang ditunjukan pada Tabel 1, didapatkan grafik kekuatan tarik dan modulus elastisitas terhadap fraksi berat pada gambar 6 dan grafik kekuatan tarik dan modulus elastisitas terhadap waktu perendaman serat pada air laut pada gambar 7 . Serta didapatkan grafik regangan tarik dan modulus elastisitas terhadap fraksi berat pada gambar 8 dan grafik regangan tarik dan modulus elastisitas terhadap waktu perendaman serat pada air laut pada gambar 9 . 


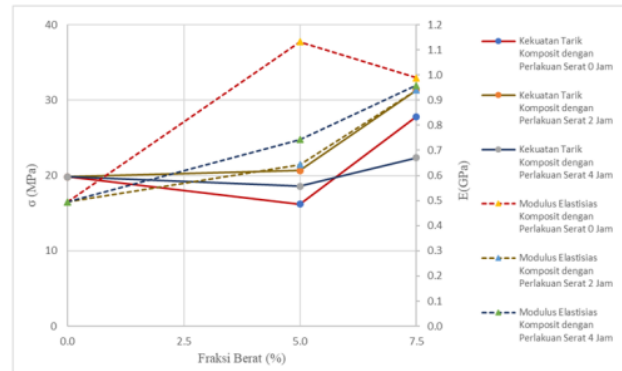

Gambar 6 Grafik sifat kekuatan tarik dan modulus elastisitas terhadap fraksi berat serat

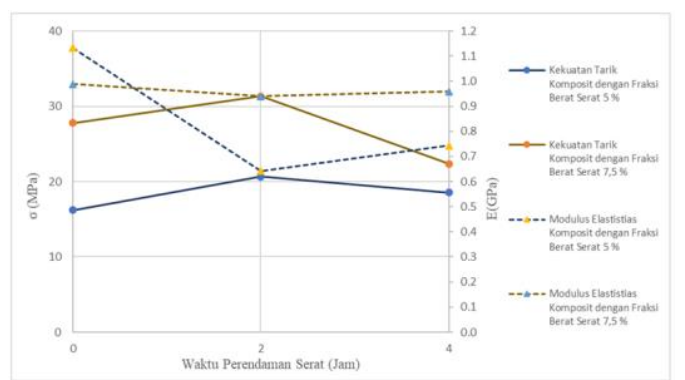

Gambar 7 Grafik sifat kekuatan tarik dan modulus elastisitas terhadap waktu perendaman serat

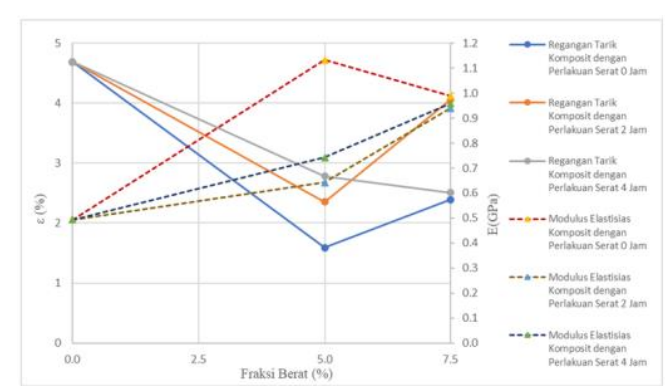

Gambar 8 Grafik sifat regangan tarik dan modulus elastisitas terhadap fraksi berat serat

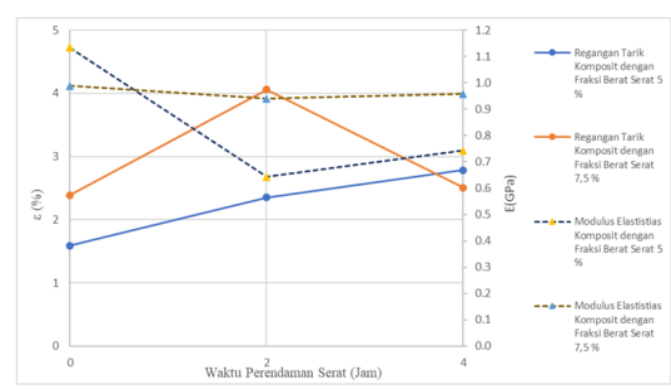

Gambar 9 Grafik sifat regangan tarik dan modulus elastisitas terhadap waktu perendaman serat

Pada Penelititan [10] menyatakan bahwa pertambahan kekuatan tarik meningkat seiring dengan bertambahya fraksi berat serat. Pada penelitian tersebut digunakan fraksi berat serat $0 \%, 5 \%, 10 \%$, dan $15 \%$ dengan perlakuan alkali perendaman pada $\mathrm{NaOH}$ selama 2 jam, diperoleh hasil terendah pada fraksi berat 0\% (Matrik Murni) yaitu 17,553 MPa, Meningkat pada fraksi berat serat 5\% menjadi 21,821 $\mathrm{MPa}$, meningkat pada fraksi berat serat $10 \%$ menjadi 22,257 Mpa dan maksimum pada fraksi berat serat 15 $\%$ dengan nilai sebesar 24,478 $\mathrm{MPa}$. Untuk pengaruh variasi waktu perendaman serat dijelaskan pada penelitian [11] bahwa kekuatan tarik tertinggi komposit dengan perlakuan alkali $5 \% \mathrm{NaOH}$ selama $0,2,4$, dan 6 jam pada serat didapat pada waktu perendaman 2 jam sebesar 190,27 MPa dan kekuatan tarik terendah pada waktu perendaman 6 jam sebesar 147,099 MPa.

Gambar 6 menunjukan hubungan antara kekuatan tarik dan modulus elastisitas terhadap fraksi berat serat. Pada fraksi berat $0 \%$ diperoleh rata-rata nilai kekuatan tarik sebesar 19,82 MPa, Nilai terendah kekuatan tarik terdapat pada fraksi berat serat 5\% perendaman serat 0 jam dengan nilai rata-rata kekuatan tarik sebesar 16,20 $\mathrm{MPa}$, meningkat pada fraksi berat 7,5\% dengan nilai rata-rata 27,79 $\mathrm{MPa}$. Perendaman serat 2 jam memiliki kekuatan tarik tertinggi disetiap fraksi. Fraksi berat $5 \%$ perendaman serat 2 jam diperoleh rata-rata nilai kekuatan tarik sebesar 20,65 $\mathrm{MPa}$, dan fraksi berat 7,5\% diperoleh kekuatan tarik maksimum dengan rata-rata sebesar 31,32 MPa. Pada perendaman serat 4 jam, fraksi berat $5 \%$ perendaman 4 jam didapatkan nilai rata-rata kekuatan tarik sebesar $18,56 \mathrm{MPa}$, dan pada fraksi berat $7,5 \%$ diperoleh nilai rata-rata kekuatan tarik sebesar 22,34 MPa. Menurut hasil dan pembahasan foto makro patahan, Penurunan kekuatan tarik pada komposit fraksi berat 5\% perlakuan perendaman serat 0 jam dan 4 jam diaktibatkan oleh ikatan antara matriks dan serat yang kurang baik. Salah satu indikator ikatan antara serat dan matriks yang kurang baik ditandai dengan terdapatnya serat yang tidak terikat dengan matriks ataupun serat dengan struktur yang rusak sehingga menghasilkan fiber pull-out. Pada foto makro patahan komposit dapat diamati juga terjadinya overload, dimana overload merupakan patahan dari serat yang berhasil terikat dengan matriks dan letaknya sejajar dengan arah dari gaya tarik. Overload sangat berpengaruh pada nilai kekuatan tarik yang dihasilkan, oleh karena itu peningkatan fraksi berat akan berpengaruh pada rasio overload yang terjadi dan akan meningkatkan nilai kekuatan tarik komposit. Komposit dengan perlakuan perendaman serat 2 jam memiliki ikatan terbaik antara matriks dan serat dibandingkan dengan komposit dengan perlakuan serat 0 jam dan 4 jam, oleh karena itu kekuatan tarik yang dhasilkan akan lebih optimum.

Gambar 8 pada fraksi berat serat $0 \%$ memiliki nilai rata-rata regangan tertinggi sebesar $4,69 \%$. Pada perendaman 0 jam diperoleh nilai rata - rata regangan terendah komposit sebesar 1,59\% Pada fraksi berat $5 \%$ dan pada fraksi berat $7,5 \%$ diperoleh regangan dengan nilai rata-rata 2,39\%. Pada perendaman 2 jam diperoleh nilai rata-rata regangan sebesar $2,35 \%$ dan meningkat dengan nilai rata-rata $4,06 \%$ pada fraksi berat 7,5\%. Pada perendaman 4 jam diperoleh nilai rata-rata regangan sebesar $2,78 \%$ dan menurun dengan nilai rata-rata $2,51 \%$ pada fraksi berat 7,5\% 
Berdasarkan gambar 6, modulus elastisitas terendah diperoleh pada fraksi berat $0 \%$ dengan nilai rata-rata $0,49 \mathrm{GPa}$. Pada perendaman 0 jam diperoleh nilai rata - rata modulus elastisitas tertinggi senilai 1,13 GPa Pada fraksi berat 5\% dan menurun dengan nilai rata-rata sebesar $0,99 \mathrm{GPa}$ pada fraksi berat 7,5 $\%$. Pada perendaman 2 jam diperoleh nilai rata-rata modulus elastisitas sebesar 0,64 GPa pada fraksi berat $5 \%$ dan meningkat dengan nilai rata-rata $0,94 \mathrm{GPa}$ pada fraksi berat 7,5\%. Pada perendaman 4 jam diperoleh nilai rata-rata modulus elastisitas sebesar $0,74 \mathrm{GPa}$ pada fraksi berat $5 \%$ dan meningkat dengan nilai rata-rata $0,96 \mathrm{GPa}$ pada fraksi berat 7,5\%.

\subsection{Uji Lentur}

Data hasil uji lentur untuk semua perlakuan dan fraksi berat serat disajikan pada tabel 2 .

Tabel 2 Data hasil uji lentur

\begin{tabular}{|c|c|c|c|c|c|c|c|c|c|}
\hline \multicolumn{10}{|c|}{ Pengujian Lentur Komposit } \\
\hline \multicolumn{10}{|c|}{ Fraksi Berat Serat 0\% } \\
\hline No. & $\mathrm{L}(\mathrm{mm})$ & $\mathrm{b}(\mathrm{mm})$ & $\mathrm{d}(\mathrm{mm})$ & $\mathrm{P}(\mathrm{N})$ & $\delta(\mathrm{mm})$ & $\mathrm{m}$ & $\sigma(\mathrm{MPa})$ & $\varepsilon(\%)$ & $\mathrm{E}(\mathrm{GPa})$ \\
\hline 01 & 48 & 12,7 & 3 & 59,486 & 6,4 & 10,270 & 37,471 & 5,000 & 0,828 \\
\hline $\mathrm{O} 2$ & 48 & 12,7 & 3 & 51,156 & 4,3 & 10,900 & 32,224 & 3,359 & 0,879 \\
\hline 03 & 48 & 12,7 & 3 & 68,992 & 8,9 & 10,165 & 43,460 & 6,953 & 0,820 \\
\hline \multicolumn{7}{|c|}{ Rata-Rata } & 37,718 & 5,104 & 0,842 \\
\hline \multicolumn{10}{|c|}{ Fraksi Berat Serat $5 \%$, Perendaman Air Laut 0 Jam } \\
\hline No. & $\mathrm{L}(\mathrm{mm})$ & $\mathrm{b}(\mathrm{mm})$ & $\mathrm{d}(\mathrm{mm})$ & $\mathrm{P}(\mathrm{N})$ & $\delta(\mathrm{mm})$ & $\mathrm{m}$ & $\sigma(\mathrm{MPa})$ & $\varepsilon(\%)$ & $\mathrm{E}(\mathrm{GPa})$ \\
\hline $\mathrm{A} 0$ & 48 & 12,7 & 3 & 73,843 & 4,8 & 13,595 & 46,515 & 3,750 & 1,096 \\
\hline A 1 & 48 & 12,7 & 3 & 68,992 & 5,4 & 10,615 & 43,460 & 4,219 & 0,856 \\
\hline $\mathrm{A} 4$ & 48 & 12,7 & 3 & 81,095 & 4,5 & 15,082 & 51,083 & 3,516 & 1,216 \\
\hline \multicolumn{7}{|c|}{ Rata- Rata } & 47,019 & 3,828 & 1,056 \\
\hline \multicolumn{10}{|c|}{ Fraksi Berat Serat 7,5\%, Perendaman Air Laut $0 \mathrm{Jam}$} \\
\hline No. & $\mathrm{L}(\mathrm{mm})$ & $\mathrm{b}(\mathrm{mm})$ & $\mathrm{d}(\mathrm{mm})$ & $\mathrm{P}(\mathrm{N})$ & $\delta(\mathrm{mm})$ & $\mathrm{m}$ & $\sigma(\mathrm{MPa})$ & $\varepsilon(\%)$ & $\mathrm{E}(\mathrm{GPa})$ \\
\hline B 0 & 48 & 12,7 & 3 & 98,490 & 3,8 & 21,887 & 62,041 & 2,969 & 1,765 \\
\hline B 1 & 48 & 12,7 & 3 & 91,826 & 3,7 & 21,980 & 57,843 & 2,891 & 1,772 \\
\hline B 2 & 48 & 12,7 & 3 & 102,802 & 3,8 & 22,104 & 64,757 & 2,969 & 1,782 \\
\hline \multirow{2}{*}{\multicolumn{7}{|c|}{ Rata-Rata }} & 61,547 & 2,943 & 1,773 \\
\hline & & & & Serat $5 \%, \mathrm{~F}$ & Perendama & Air Laut 2 & Jam & & \\
\hline No. & $\mathrm{L}(\mathrm{mm})$ & $\mathrm{b}(\mathrm{mm})$ & $\mathrm{d}(\mathrm{mm})$ & $\mathrm{P}(\mathrm{N})$ & $\delta(\mathrm{mm})$ & $\mathrm{m}$ & $\sigma(\mathrm{MPa})$ & $\varepsilon(\%)$ & $\mathrm{E}(\mathrm{GPa})$ \\
\hline $\mathrm{C} 1$ & 48 & 12,7 & 3 & 82,369 & 5,9 & 16,654 & 51,886 & 4,609 & 1,343 \\
\hline $\mathrm{C} 2$ & 48 & 12,7 & 3 & 81,830 & 5,3 & 12,566 & 51,546 & 4,141 & 1,013 \\
\hline $\mathrm{C} 3$ & 48 & 12,7 & 3 & 82,761 & 4,8 & 14,212 & 52,133 & 3,750 & 1,146 \\
\hline \multicolumn{7}{|c|}{ Rata- Rata } & 51,855 & 4,167 & 1,167 \\
\hline \multicolumn{10}{|c|}{ Fraksi Berat Serat 7,5\%,Perendaman Air Laut 2 Jam } \\
\hline No. & $\mathrm{L}(\mathrm{mm})$ & $\mathrm{b}(\mathrm{mm})$ & $\mathrm{d}(\mathrm{mm})$ & $\mathrm{P}(\mathrm{N})$ & $\delta(\mathrm{mm})$ & $\mathrm{m}$ & $\sigma(\mathrm{MPa})$ & $\varepsilon(\%)$ & $\mathrm{E}(\mathrm{GPa})$ \\
\hline D0 & 48 & 12,7 & 3 & 118,090 & 4,2 & 22,092 & 74,387 & 3,281 & 1,781 \\
\hline $\mathrm{D} 2$ & 48 & 12,7 & 3 & 128,870 & 5,4 & 19,941 & 81,178 & 4,219 & 1,608 \\
\hline D4 & 48 & 12,7 & 3 & 108,094 & 4,9 & 18,635 & 68,091 & 3,828 & 1,503 \\
\hline \multirow{2}{*}{\multicolumn{10}{|c|}{\begin{tabular}{|l|l|} 
Rata- Rata & 74,552 \\
Fraksi Berat Serat 5\%, Perendaman Air Laut 4 Jam \\
\end{tabular}}} \\
\hline & & & & & & & & & \\
\hline No. & $\mathrm{L}(\mathrm{mm})$ & $\mathrm{b}(\mathrm{mm})$ & $\mathrm{d}(\mathrm{mm})$ & $\mathrm{P}(\mathrm{N})$ & $\delta(\mathrm{mm})$ & $\mathrm{m}$ & $\sigma(\mathrm{MPa})$ & $\varepsilon(\%)$ & $\mathrm{E}(\mathrm{GPa})$ \\
\hline E0 & 48 & 12,7 & 3 & 75,852 & 5,8 & 12,384 & 47,781 & 4,531 & 0,999 \\
\hline E1 & 48 & 12,7 & 3 & 68,355 & 5,7 & 11,067 & 43,058 & 4,453 & 0,892 \\
\hline E2 & 48 & 12,7 & 3 & 65,268 & 4,9 & 12,404 & 41,114 & 3,828 & 1,000 \\
\hline \multicolumn{7}{|c|}{ Rata- Rata } & 43,984 & 4,271 & 0,964 \\
\hline \multicolumn{10}{|c|}{ Fraksi Berat Serat 7,5\%, Perendaman Air Laut 4 Jam } \\
\hline No. & $\mathrm{L}(\mathrm{mm})$ & $\mathrm{b}(\mathrm{mm})$ & $\mathrm{d}(\mathrm{mm})$ & $\mathrm{P}(\mathrm{N})$ & $\delta(\mathrm{mm})$ & $\mathrm{m}$ & $\sigma(\mathrm{MPa})$ & $\varepsilon(\%)$ & $\mathrm{E}(\mathrm{GPa})$ \\
\hline F1 & 48 & 12,7 & 3 & 95,305 & 3,7 & 20,977 & 60,035 & 2,891 & 1,691 \\
\hline F2 & 48 & 12,7 & 3 & 101,626 & 4,5 & 18,957 & 64,016 & 3,516 & 1,529 \\
\hline F3 & 48 & 12,7 & 3 & 103,390 & 4,1 & 21,023 & 65,128 & 3,203 & 1,695 \\
\hline \multicolumn{7}{|c|}{ Rata-Rata } & 63,060 & 3,203 & 1,638 \\
\hline
\end{tabular}

Berdasarkan data yang ditunjukan pada Tabel 2, didapatkan grafik kekuatan lentur dan modulus elastisitas terhadap fraksi berat pada gambar 10 dan grafik kekuatan lentur dan modulus elastisitas terhadap waktu perendaman serat pada air laut pada gambar 11. Serta didapatkan grafik regangan lentur dan modulus elastisitas terhadap fraksi berat pada gambar 12 dan grafik regangan lentur dan modulus elastisitas terhadap waktu perendaman serat pada air laut pada gambar 13.

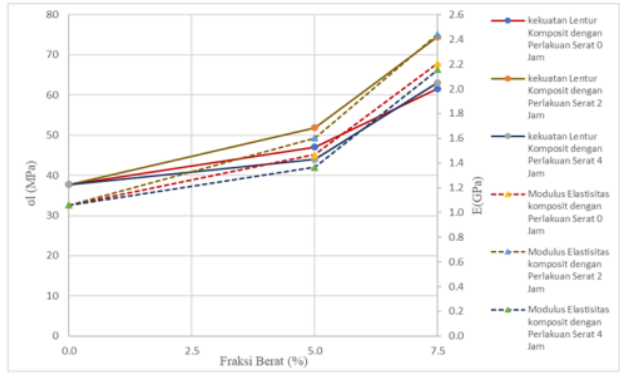

Gambar 10 Grafik sifat kekuatan lentur dan modulus elastisitas terhadap fraksi berat serat

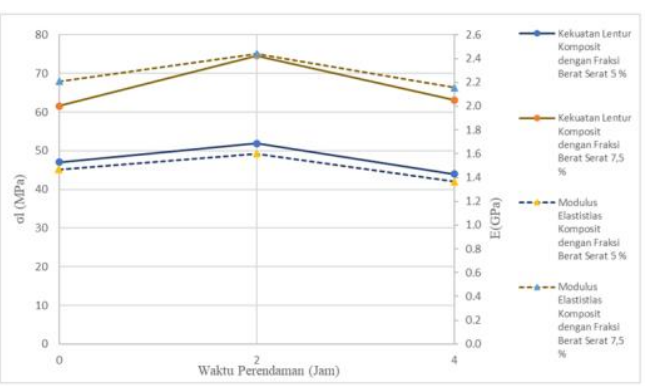

Gambar 11 Grafik sifat kekuatan lentur dan modulus elastisitas terhadap waktu perendaman serat

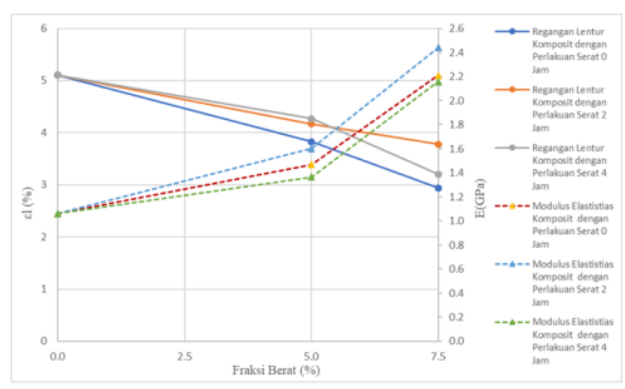

Gambar 12 Grafik sifat regangan lentur dan modulus elastisitas terhadap fraksi berat serat

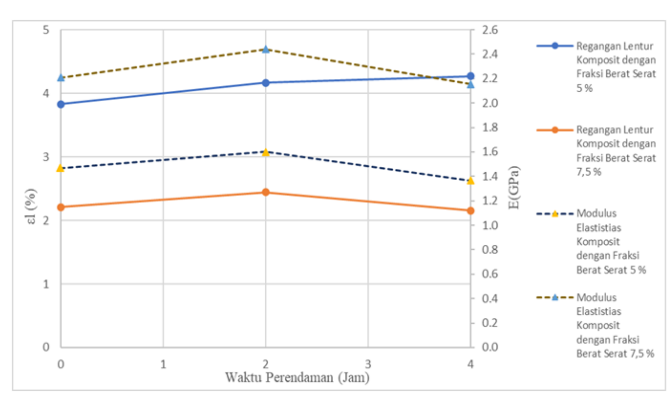

Gambar 13 Grafik sifat regangan lentur dan modulus elastisitas terhadap waktu perendaman serat

Pada penelitian Sudiarsa et al., (2018) meyatakan semakin besar fraksi berat serat dalam komposit maka kekuatan tarik semakin meningkat begitu pula kekuatan lentur dari sebuah komposit. Untuk pengaruh waktu perendaman serat, dinyatakan pada penelitian Diharjo, (2006) bahwa waktu perendaman serat pada alkali yang optimum adalah 2 jam. Perendaman serat lebih lama akan menyebabkan degradasi pada sifat mekanis serat, bahkan dapat meyebabkan serat menjadi rapuh. 
Berdasarkan gambar 10, kekuatan lentur rata-rata terendah terdapat di fraksi berat serat $0 \%$ senilai $37,72 \mathrm{MPa}$. Pada perendaman serat 0 jam didapatkan nilai rata- rata $47,02 \mathrm{MPa}$ pada fraksi berat $5 \%$ dan meningkat menjadi $61,57 \mathrm{MPa}$ pada fraksi berat 7,5 $\%$. Pada perendaman serat 2 jam didapat nilai kekuatan lentur sebesar 51,86 MPa pada fraksi berat $5 \%$ dan nilai kekuatan maksimum komposit pada fraksi berat $7,5 \%$ sebesar 74,55 $\mathrm{MPa}$. Pada perendaman fraksi berat 4 jam didapat penurunan nilai rata-rata dibandingkan dengan perendaman 0 jam pada fraksi berat $5 \%$ dan perendaman serat 2 jam pada fraksi berat $5 \%$ dan 7,5\%. Pada fraksi berat $5 \%$ perendaman serat 4 jam didapat nilai rata-rata sebesar 43,98 MPa dan meningkat menjadi 63,06 MPa pada fraksi berat 7,5\% perendaman serat 4 jam. Kekuatan lentur komposit meningkat seiring dengan meningkatnya fraksi berat serat. Perlakuan perendaman serat 2 jam menghasilkan kekuatan lentur maksimum dikarenakan terjadinya ikatan serat yang baik, didapat penurunan kekuatan lentur pada perlakuan perendaman 4 jam dikarenakan degradasi pada jaringan serat yang mengakibatkan ikatan serat dan matriks lebih rapuh.

Berdasarkan gambar 12, dapat dilihat bahwa terjadi penurunan regangan seiring dengan pertambahan fraksi berat pada setiap variasi perendaman serat. pada komposit dengan $0 \%$ serat memiliki regangan yang paling tinggi dengan nilai $5,10 \%$. Untuk perendaman 0 jam didapatkan hasil $3,83 \%$ pada fraksi berat $5 \%$ dan menurun pada fraksi berat 7,5 \% dengan nilai 2,94 \% yang merupakan regangan terendah. Pada perendaman 2 jam didapatkan hasil dengan nilai $4,17 \%$ dan menurun pada fraksi berat $7,5 \%$ dengan nilai $3,78 \%$. Pada perendaman 4 jam didapatkan hasil dengan nilai $4,27 \%$ dan menurun pada fraksi berat $7,5 \%$ dengan nilai $3,203 \%$.

Berdasarkan gambar 10 , nilai rata-rata modulus elastisitas meningkat seiringan dengan meningkatnya fraksi berat. Hal ini disebabkan oleh peningkatan rasio tegangan lentur terhadap regangan lentur. Fraksi berat $0 \%$ serat memiliki modulus elastisitas terendah senilai 1,06 GPa. Pada variasi perendaman 0 jam, fraksi berat 5\% menghasilkan modulus elastisitas sebesar 1,47 GPa dan meningkat pada fraksi berat 7,5\% menjadi 2,21 GPa. Untuk variasi perendaman 2 jam, fraksi berat $5 \%$ menghasilkan modulus elastisitas sebesar 1,60 $\mathrm{GPa}$ dan meningkat pada fraksi berat $7,5 \%$ menjadi 2,44 GPa. Untuk variasi perendaman 4 jam, fraksi berat $5 \%$ menghasilkan modulus elastisitas sebesar 1,37 GPa dan meningkat pada fraksi berat $7,5 \%$ menjadi $2,16 \mathrm{GPa}$.

\subsection{Pengamatan Foto Makro Patahan}

Dilakukan pengambilan data foto makro dari hasil patahan spesimen uji komposit. Adapun hasil foto makro sebagai berikut :

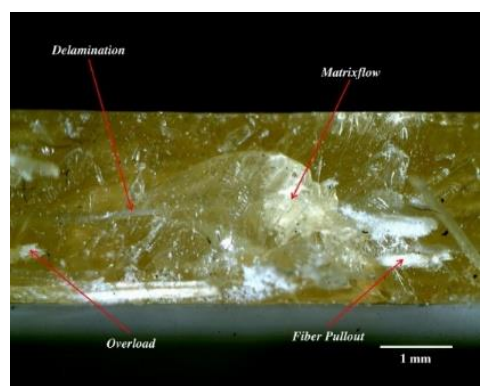

Gambar 14 Foto Makro Patahan Komposit Fraksi berat 5\% perendaman serat 0 jam

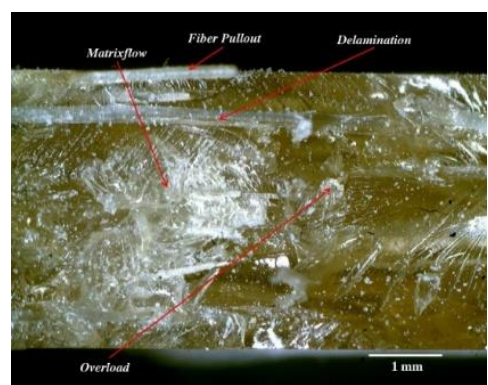

Gambar 15 Foto Makro Patahan Komposit Fraksi berat 7,5\% perendaman serat 0 jam

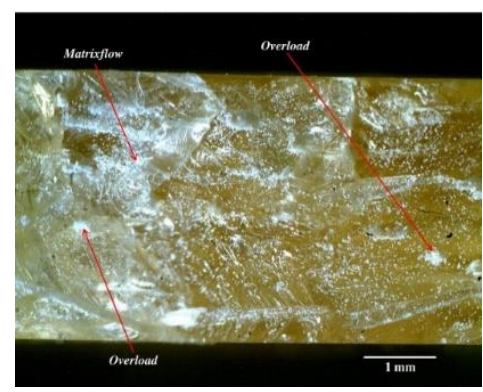

Gambar 16 Foto Makro Patahan Komposit Fraksi berat $5 \%$ perendaman serat 2 jam

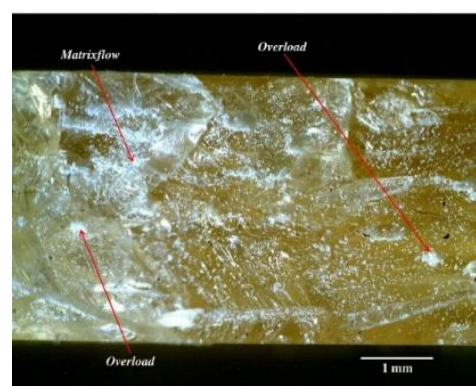

Gambar 17 Foto Makro Patahan Komposit Fraksi berat 7,5\% perendaman serat 2 jam 


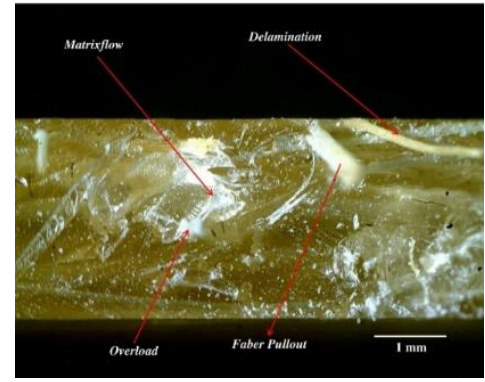

Gambar 18 Foto Makro Patahan Komposit Fraksi berat $5 \%$ perendaman serat 4 jam

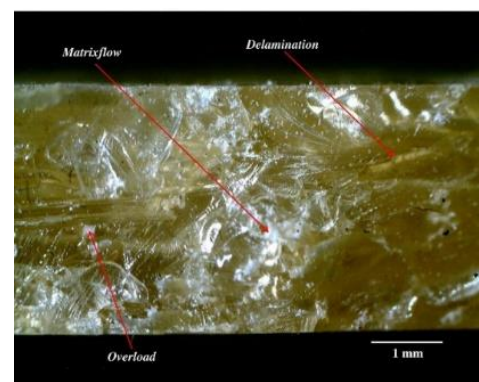

Gambar 19 Foto Makro Patahan Komposit Fraksi berat 7,5\% perendaman serat 4 jam

Berdasarkan pada gambar 14, patahan pada komposit dengan perendaman serat selama 0 jam fraksi berat $5 \%$ didominasi oleh matriks flow sebesar $44,76 \%$. Hal tersebut diaktibatkan oleh kurangnya serat pada area patahan serta terdapat beberapa delaminasi yang ditimbulkan karena orientasi serat acak. pada gambar 15, komposit fraksi berat 7,5\% dengan perendaman 0 jam didominasi oleh matriks flow sebesar $34,22 \%$. Delaminasi yang timbul lebih banyak dibandingkan pada fraksi berat 5\%, tetapi memiliki lebih sedikit fiber pull-out dan lebih banyak overload. Pada gambar 16, komposit fraksi berat 5\% dengan perendaman 2 jam didapat matriks flow sebesar 7,92\%. pada gambar 17, komposit fraksi berat $7,5 \%$ didapat matriks flow sebesar $44,39 \%$. Untuk gambar 18, komposit fraksi berat 5\% perendaman serat 4 jam didapat matriks flow sebesar $26,31 \%$. Pada gambar 19, komposit fraksi berat $7,5 \%$ perendaman serat 4 jam didapat matriks flow sebesar $48,23 \%$. Pengamatan hasil patahan menyatakan bahwa perendaman serat optimal adalah perendaman serat 2 jam. Hal ini dinyatakan oleh tidak adanya fiber pullout dan terjadinya overload yang lebih banyak dibandingkan variasi lainnnya.Untuk Perendaman serat 0 jam komposit memiliki ikatan cross-linking yang kurang baik sedangkan perendaman serat 4 jam serat mulai terdegradasi sehingga serat menajdi rapuh dan tidak dapat berikatan dengan baik.

\subsection{Pengamatan Mikro Permukaan}

Dilakukan pengambilan data foto mikro permukaan dari spesimen uji komposit. Adapun hasil foto mikro sebagai berikut :
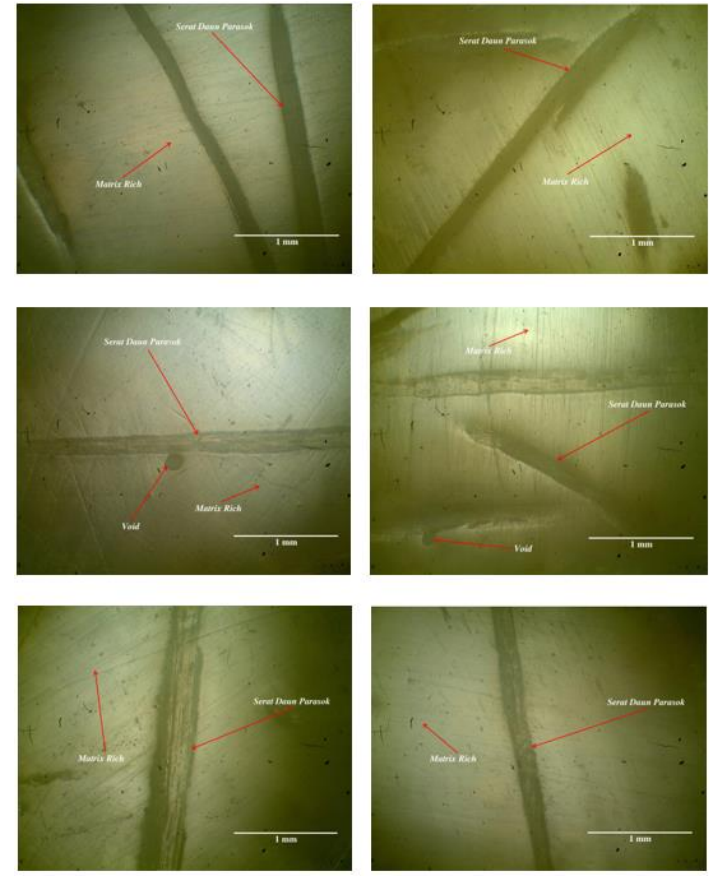

Gambar 20 Hasil foto mikro permukaan komposit dengan perbesaran $40 \times$
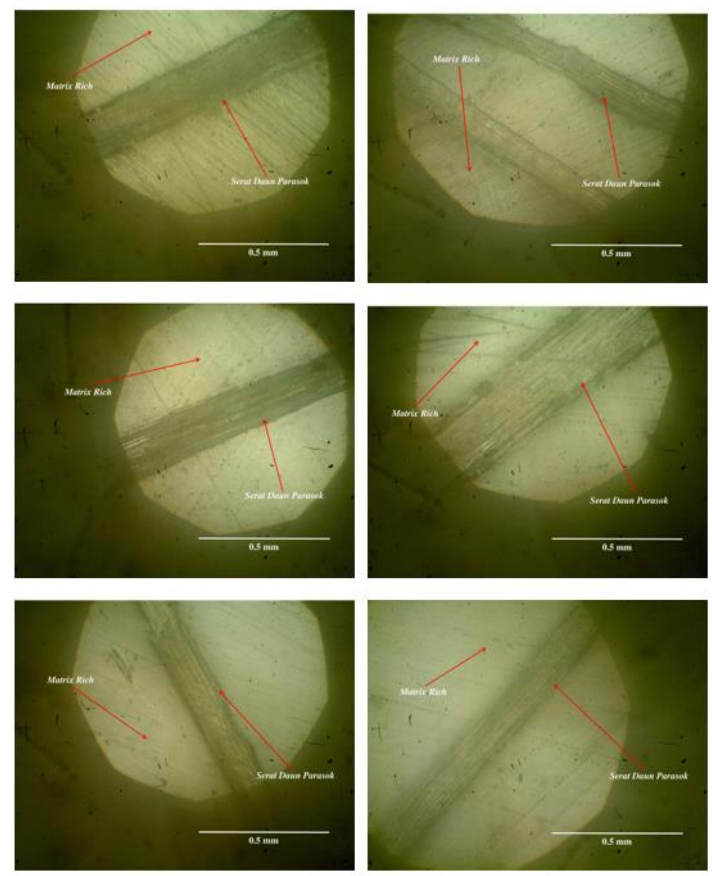

Gambar 21 Hasil foto mikro permukaan komposit dengan perbesaran $100 \times$

\section{SIMPULAN}

Dari hasil penelitian dan pembahasan, dapat diambil beberapa kesimpulan sebagai berikut:

1. Kekuatan tarik tertinggi terjadi pada fraksi berat serat $7,5 \%$ dan perendaman serat selama 2 jam dengan nilai rata - rata tegangan tarik sebesar 31,316 $\mathrm{MPa}$, sedangkan kekuatan tarik terendah terjadi pada fraksi berat serat $5 \%$ perendaman serat 0 jam (tanpa perendaman) dengan nilai rata rata tegangan tarik sebesar 16,203 $\mathrm{MPa}$. 
2. Nilai kekuatan lentur tertinggi terjadi pada fraksi berat serat $7,5 \%$ dan perendaman serat 2 jam dengan nilai rata - rata tegangan lentur sebesar 74,552 $\mathrm{MPa}$, sedangkan kekuatan lentur terendah terjadi pada fraksi berat serat $0 \%$ (resin murni) dengan nilai rata - rata tegangan lentur sebesar $37,718 \mathrm{MPa}$

\section{KEPUSTAKAAN}

[1] Djamil, S., Sobron Y Lubis, \& Hartono. (2014). Kekuatan Tarik Komposit Matrik Polimer Berpenguat Serat Alam Bambu Gigantochloa Apus Jenis Anyaman Diamond Braid dan Plain Weave. 1-8.

[2] Suryawan, I. G. P. A., Suardana, N., Suarsana, I. K., Lokantara, I. P., \& Lagawa, I. K. J. (2019). Kekuatan Tarik dan Lentur pada Material Komposit Berpenguat Serat Jelatang. Jurnal Energi Dan Manufaktur, 12(1), 7. https://doi.org/10.24843/jem.2019.v12.i01.p02

[3] Budhi Santoso, A. (2007). Pengaruh Perlakuan Kimia Pada Serat Widuri ( Calotropis Gigantea ) Terhadap Sifat Mekanis Komposit The Effects Of Chemical Treatment On Widuri ( Calotropis Gigantea ) Fiber To Mechanical Properties.

[4] Susanto, J., Seputro, H., \& Santoso, E. (2016). Analisa Pengaruh Variasi Media Pendingin Dan Waktu Aging Pada Perlakuan Panas T6 Terhadap Struktur Mikro. 01(02), 227-238.

[5] Wambua, P., I., \& J., V. (2003). Natural Fibres: Can They Replace Glass In Fiber Reinforced Plastics? Composites Science Technology

[6] Jones, G. (1975). Front Matter. In Joanna Russ. https://doi.org/10.5406/j.ctvnwbxjm.1

[7] Thakur, V. K., Gupta, R., \& Thakur, M. K. (2017). Hybrid Polymer Composite Materials: Processing.

[8] Czarnecki, L. (2018). Polymer-Concrete Composites for the repair of concrete structures. MATEC Web of Conferences, 199. https://doi.org/10.1051/matecconf/20181990100 $\underline{6}$

[9] Frederick, J. E. (2008). Principles of Atmospheric Science

[10] Wirawan, I.G.R.T, Surata, I.W, Nindhia, T.G.T (2018). Pengaruh Fraksi Berat Terhadap Kekuatan Tarik Dan Lentur Komposit Polyester Serat Serabut Kelapa.

[11] Diharjo, K. (2006). Pengaruh Perlakuan Alkali terhadap Sifat Tarik Bahan Komposit Serat Rami-Polyester 